\title{
Cytology profile and age influence in the equine bronchoalveolar lavage in healthy and asymptomatic inflammatory airway disease
}

\author{
Perfil citológico e influência da idade no lavado broncoalveolar de equinos sadios e com doença \\ inflamatória de vias aéreas assintomática
}

\author{
Eliene Porto Sad ${ }^{\mathrm{I}}$ Nayro Xavier de Alencar ${ }^{\mathrm{II}}$ Vanessa Viscardi ${ }^{\mathrm{II}}$ Maria Fernanda de Mello Costa ${ }^{\mathrm{IV}}$ \\ Tanja Maria Hess ${ }^{\mathrm{V}}$ Daniel Augusto Barroso Lessa ${ }^{\mathrm{II}}$
}

\section{RESUMO}

\begin{abstract}
Doenças inflamatórias pulmonares são observadas na espécie equina desde sua domesticação. Dentre as enfermidades de maior importância do trato respiratório equino, estão os distúrbios não infecciosos de vias aéreas posteriores. Este trabalho teve por objetivo determinar o perfil citológico e o efeito da idade na avaliação do lavado broncoalveolar (LBA) de equinos sadios e com Doença Inflamatória das Vias Aéreas (DIVA) assintomática. Foram utilizados 32 equinos adultos, aparentemente sadios, de ambos os sexos $(20$ machos e 12 fêmeas), com faixa etária média semelhante, sendo 15 animais do grupo controle e 17 animais do grupo doente assintomático. Os grupos foram estabelecidos segundo os critérios de GERBER et al. (2004) para acúmulo de muco traqueal após a realização de exames físicos diretos e endoscopia traqueal. Foi realizado o LBA e o percentual dos valores médios obtidos na análise citológica dos cavalos sadios e com DIVA assintomática foram, respectivamente: $56,9 \%$ e 48,0\% de macrófagos, $37,2 \%$ e 40,0\% de linfócitos, $3,3 \%$ e $7,1 \%$ de neutrófilos, $1,7 \%$ e $1,4 \%$ de mastócitos, $0,3 \%$ e $0,7 \%$ de eosinófilos; e $0,5 \%$ e $0,4 \%$ de células epiteliais. Concluiu-se que a DIVA nos animais integrantes do grupo doente assintomático caracterizou- se por um discreto infiltrado de neutrófilos e que a idade não influencia na avaliação citológica do LBA.
\end{abstract}

Palavras-chave: equino, doença inflamatória das vias aéreas, citologia broncoalveolar.

\section{ABSTRACT \\ Pulmonary inflammatory diseases have been observed in equine since their domestication. Non-infectious disease processes of the lower airways are amongst the most}

\begin{abstract}
important diseases of the equine respiratory tract. This study aims to determine the cytology profile and effect of age on the evaluation of equine bronchoalveolar lavage (BAL) obtained from healthy animals and from horses with asymptomatic inflammatory airway disease (IAD). Thirty two horses, including 20 males and 12 females, without clinical signs of pulmonary disease and with age varying from 4 to 21 years, were assigned to two groups: 15 animals in the control group and 17 in the asymptomatic group. Groups were divided according to physical examination and mucous accumulation observed during tracheal endoscopy. The BAL results from healthy and asymptomatic horses were, respectively: $56.9 \%$ and $48.0 \%$ macrophages, $37.2 \%$ and $40.0 \%$ lymphocytes, $3.3 \%$ and $7.1 \%$ neutrophils, $1.7 \%$ and $1.4 \%$ mast cells, $0.3 \%$ and $0.7 \%$ eosinophils; $0,5 \%$ and $0.4 \%$ epithelial cells. When horses in the two groups were analyzed according to their age range, no differences were found. In conclusion, IAD in the asymptomatic group was significantly different from the control group. The asymptomatic horses presented a discrete infiltrate of neutrophils, which does not influence cytological evaluation of BAL.
\end{abstract}

Key words: horse; inflammatory airway disease; bronchoalveolar cytology.

\section{INTRODUCTION}

Respiratory diseases are the most common source of economic losses in the world equestrian industry (HODGSON \& HODGSON, 2002) and inflammatory airway disease (IAD) is one of the most important pulmonary afflictions in sport horses. With

\footnotetext{
'Deparmanento de Patologia e Clínica Veterinária, Universidade Federal Fluminense (UFF), Rua Vital Brasil Filho, 64, 24230-340, Niterói, RJ, Brasil. E-mail: elienesad@gmail.com. Autor para correspondência.

"Departamento de Patologia e Clínica Veterinária, UFF, Niterói, RJ, Brasil.

"IITenente Veterinário do Exército Brasileiro, Rio de Janeiro, RJ, Brasil.

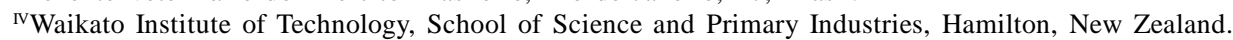

${ }^{v}$ Equine Science Department, Colorado State University, Fort Collins, CO.
} 
the exception of decreased performance, the majority of horses presenting IAD demonstrate only mild clinical signs, very often only detected under maximum physical effort (LESSA et al., 2008).

This condition is still not completely understood, especially due to the lack of agreement among researchers concerning cytology patterns obtained from bronchoalveolar samples from healthy and IAD positive horses. The main reasons for the lack of agreement are the variety of techniques used to perform the bronchoalveolar lavage (BAL) (WINDER et al., 1989; VRINS et al., 1991; LAPOINTE et al., 1994), the presence of asymptomatic disease the degree of exposure to contaminants and environment allergens (MAIR et al., 1987), and differences in age of the subjects (VIEL \& HEWSON, 2003). This study has the objective to determine the cytology profile and the effect of age on the evaluation of BAL samples obtained from healthy and asymptomatic IAD horses.

\section{MATERIAL AND METHODS}

The samples were taken from 32 adult horses of mixed breeds, belonging to Brazilian Army (Regimento de Cavalaria de Guardas Andrade Neves), in Rio de Janeiro, Brazil. Twenty males and 12 females with ages ranging from four to 21 years utilized in moderate intensity sport activity were recruited to participate in the study. The horses were apparently healthy, had no disease history or medical treatment during the 30 days preceding data collection. Blood sample were collected from the horses and analyzed for $\mathrm{WBC}$ and plasma fibrinogen and values were within normality according to published parameters (GRONDIN \& DEWITT, 2010).

The horses were kept in semi-confinement, in stall boxes of $9 \mathrm{~m}^{2}$, with cement floor and no bedding. Feeding included 5 to $6 \mathrm{~kg} \mathrm{animal}^{-1} \mathrm{day}^{-1}$ of commercial horse concentrate with $12 \%$ total protein, four $\mathrm{kg}$ of Coast-Cross grass hay/animal/day and water $a d$ libitum. The animals were groomed daily and turned out for voluntary exercise in a paddock 4 to 6 times a week during 6 hours a day. The subjects were dewormed every three months and vaccinated against influenza, tetanus, eastern and western encephalomyelitis, rabies, equine adenitis and leptospirosis.

Normal horses were selected after being clinically evaluated and reference values were considered normal for vital functions as described by HOUSTON \& RADOSTITS (2002) and normal for pulmonary percussion and auscultation according to MCGORUM et al. (2002).

Only one endoscopic examination was conducted on each experiment animal in the mornings, with an Olympus CF 10L colonoscope advanced from the nasal cavity up to the tracheal carina. Both nasal cavities were examined. The trachea was considered normal when presented intact, with shiny mucous membranes of pale color and a sharp carina (DIXON, 1997). The semi-quantitative evaluation of the tracheal mucous was conducted using a score from 0 to 5, according to GERBER et al. (2004).

Animals were classified as normal or asymptomatic based on the results from endoscopic examinations, and further sub classified according to age group into mature (older than seven years old) and younger (<seven year old) according AINSWORTH (2010). Overall there were 15 animals in the control group (normal physical examination and endoscopic scores of 0 or 1), subdivided into young control (nine horses) and mature control (six horses). The asymptomatic group consisted of 17 animals (normal physical examination but endoscopic evidence of disease demonstrated by scores 2 to 5), and was subdivided into young asymptomatic (nine horses) and mature asymptomatic (eight horses).

Those horses were mechanically restrained and sedated with intravenous $10 \%$ xylazine chloridrate $\left(\mathrm{SEDAZINE}^{\circledR}\right.$ ) at 0.5 to $1.1 \mathrm{mg} \mathrm{kg}^{-1}$ before BAL collection. An equine silicone BAL catheter $\left(\right.$ BIVONA $^{\circledR}$ ) was introduced up to the bronchi while topical anesthesia of the respiratory tract was achieved by $0.5 \%$ lidocaine $\left(\right.$ LIDOVET $\left.^{\oplus}\right)$. A BAL sample was obtained by infusing $250 \mathrm{ml}$ of warm $\left(37^{\circ} \mathrm{C}\right) 0.9 \%$ saline according to the technique described by HOFFMAN \& VIEL (1997).

Samples were considered adequate if at least $40 \%$ of the infused liquid was recovered (ROBINSON, 2001) and when surfactant and turbidity were observed. Liquid collected was transferred to glass vials and kept refrigerated at $4-6^{\circ} \mathrm{C}$ until processing, within a maximum of four hours from sampling.

Slides from the samples were obtained by cytocentrifugation (CYTOPRO 7620, WESCOR ${ }^{\circledR}$ ) at $110 \mathrm{~g}$ for five minutes, supernatant was fixated with metallic alcohol and stained with May-Grunwald, Giemsa $\left(\operatorname{Merck}^{\circledR}\right)$. Readings were conducted on an optic microscope with magnification 1000x (immersion) by differential counting of 500 cells.

Differences between groups and the effect of age were analyzed by ANOVA (SAS Institute Inc., Cary, NC) and significance level set at 5\%.

\section{RESULTS AND DISCUSSION}

The mean percentage of differential nucleated cell count in each of the groups is presented in tables 1 and 2. BAL cytology profile of the control 
Table 1 - Percentage of the differential cell count present in equine BAL from control and asymptomatic groups. Rio de Janeiro, May to December 2006.

\begin{tabular}{lcccccc}
\hline Group & Macrophages & Lymphocytes & Neutrophils & Mast cells & Eosinophils & Epithelial Cells \\
\hline Control $(\mathrm{n}=15)$ & $56.9 \pm 14.8^{\mathrm{a}}$ & $37.2 \pm 15.4^{\mathrm{a}}$ & $3.3 \pm 1.5^{\mathrm{a}}$ & $1.7 \pm 1.2^{\mathrm{a}}$ & $0.3 \pm 0.4^{\mathrm{a}}$ & $0.5 \pm 1.2^{\mathrm{a}}$ \\
Asymptomatic $(\mathrm{n}=17)$ & $48.0 \pm 14.0^{\mathrm{a}}$ & $40.0 \pm 12.2^{\mathrm{a}}$ & $7.1 \pm 3.8^{\mathrm{b}}$ & $1.4 \pm 1.1^{\mathrm{a}}$ & $0.7 \pm 1.3^{\mathrm{a}}$ & $0.4 \pm 0.9^{\mathrm{a}}$ \\
\hline
\end{tabular}

Different letters in the same column indicate significant differences (ANOVA; $\mathrm{P}<0.05$ ).

group ( $\mathrm{n}=15)$ was characterized by the prevalence of alveolar macrophages and lymphocytes, followed by neutrophils, mast cells, eosinophils and a small percentage of epithelial cells (Table 1). These results are similar to the ones described by COUËTIL \& DENICOLA (1999), HOFFMAN (1999; 2008), LESSA (2003) and in a recent IAD Workshop (ROBINSON, 2003) where volumes between 200 and $500 \mathrm{ml}$ were used in the collections of BAL.

IAD in the asymptomatic group was characterized by the presence of a discrete neutrophil infiltrate, without significant changes in other cell types (Table 1). This type of infiltrate has been described, sometimes together with increased numbers of mast cells and eosinophils (MOORE et al., 1995; BAIN, 1997; VIEL, 1997; LESSA, 2003; LESSA et al., 2005; ROBINSON, 2003). CHRISTLEY \& RUSH (2007) characterize IAD as an inflammatory process with a neutrophilic infiltrate, and less commonly with eosinophilic and mast cell infiltrates.

Age did not significantly influence the differential nucleated cell count results on the BAL of the healthy controls when young and mature animals were compared (Table 2). This finding differ from what has been previously described by HOFFMAN (1999) and VIEL \& HEWSON (2003), who demonstrated that healthy animals present a physiologic increase in neutrophil numbers with age. A similar situation was observed in the asymptomatic group, with no significant influence of age on the BAL results between asymptomatic young and mature horses (Table 2).

A small infused volume during collection of the BAL sample might result in an increase in neutrophil numbers due to relative high concentration of cells per volume retrieved (SWEENEY et al., 1992). However this factor is unlikely to have influenced the results displayed here, since the infused volume was fixed at $250 \mathrm{ml}$ for both groups and the retrieved volume was a minimum of $40 \%$ of the total infused, according to guidelines from the International Workshop on Equine Chronic Airway Disease (ROBINSON, 2001).

Even though the volume of $250 \mathrm{ml}$ is considered small by SWEENEY et al. (1992) and HOFFMAN (1999), only the percentage of neutrophils was significantly different between control and asymptomatic horses. If the difference observed had been caused by a lower dilution, all cell types would have been equally affected. Therefore we can conclude that the difference in neutrophil count between these two groups is related to the diseased pulmonary status of the asymptomatic animals.

The results from this work concur with previous information stating that the cytology profile, especially the neutrophil percentage, differs between healthy horses and the ones with asymptomatic IAD.

Table 2 - Percentage of the differential cell count present in equine BAL from control (cont) and asymptomatic (asym) groups, subdivided by age group, young (y) and mature (M). Rio de Janeiro, May to December 2006.

\begin{tabular}{|c|c|c|c|c|c|c|c|}
\hline Group & & Macrophages & Lymphocytes & Neutrophils & Mast cells & Eosinophils & Epithelial Cells \\
\hline \multirow{2}{*}{ Cont } & $Y(n=9)$ & $54.2 \pm 13.7^{\mathrm{a}}$ & $40.0 \pm 14.4^{\mathrm{a}}$ & $3.4 \pm 1.4^{\mathrm{a}}$ & $1.7 \pm 1.3^{\mathrm{a}}$ & $0.3 \pm 0.3^{\mathrm{a}}$ & $0.1 \pm 0.3^{\mathrm{a}}$ \\
\hline & $M(n=6)$ & $58.3 \pm 13.3^{\mathrm{a}}$ & $35.3 \pm 14.0^{\mathrm{a}}$ & $3.0 \pm 1.8^{\mathrm{a}}$ & $2.2 \pm 0.9^{\mathrm{a}}$ & $0.2 \pm 0.4^{\mathrm{a}}$ & $1.0 \pm 1.8^{\mathrm{a}}$ \\
\hline \multirow{2}{*}{ Asym } & $Y(n=9)$ & $54.8 \pm 12.2^{\mathrm{a}}$ & $34.7 \pm 12.1^{\mathrm{a}}$ & $8.1 \pm 3.4^{\mathrm{a}}$ & $1.3 \pm 1.0^{\mathrm{a}}$ & $0.4 \pm 1.0^{\mathrm{a}}$ & $0.6 \pm 1.3^{\mathrm{a}}$ \\
\hline & $\mathrm{M}(\mathrm{n}=8)$ & $40.8 \pm 11.7^{\mathrm{a}}$ & $46.0 \pm 10.0^{\mathrm{a}}$ & $6.0 \pm 4.2^{\mathrm{a}}$ & $1.4 \pm 1.3^{\mathrm{a}}$ & $1.2 \pm 1.5^{\mathrm{a}}$ & $0.2 \pm 0.3,^{\mathrm{a}}$ \\
\hline
\end{tabular}

Different letter in the same column indicate significant differences (ANOVA; $\mathrm{P}<0.05$ ). 


\section{CONCLUSION}

In conclusion, IAD in asymptomatic horses is characterized by a neuthrophil infiltrate and age does not influence cytological evaluation of BAL.

\section{BIOETHICS AND BIOSSECURITY COMMITTEE APPROVAL}

Protocol number CEUA/126 UFF.

\section{REFERENCES}

AINSWORTH, D.M. Review of recurrent airway obstruction (RAO, Heaves): diagnosis and treatment options. In: AMERICAN ASSOCIATION OF EQUINE PRACTITIONERS - FOCUS ON UPPER AND LOWER RESPIRATORY DISEASES, 2010, Salt Lake City, UT, USA. Proceedings... Salt Lake City: AAEP Foundation, 2010. p.100-106.

BAIN, F.T. Cytology of the respiratory tract. Respiratory medicine in ambulatory practice. Veterinary Clinics of North America: Equine Practice, v.13, n.3, p. 477-486, 1997.

CHRISTLEY, R.; RUSH, B.R. Inflammatory airway disease. In: McGORUM, B.C. et al. Equine respiratory medicine and surgery. Philadelphia: Saunders Elsevier, 2007. Cap.42, p.591-595.

COUËTIL, L.L.; DENICOLA, D.B. Blood gas, plasma lactate and bronchoalveolar lavage cytology analyses in racehorses with respiratory disease. Equine Veterinary Journal, v.31, n.S30, p.77-82, 1999.

DIXON, P.M. Ancillary diagnostic techniques for the investigation of equine pulmonary disease. Equine Veterinary Education, v.9, n.2, p.72-80, 1997.

GERBER, V. et al. Endoscopic scoring of mucus quantity and quality: observer and horse variance and relationship to inflammation, mucus viscoelasticity and volume. Equine Veterinary Journal, v.36, n.7, p.576-582, 2004.

GRONDIN, T.M.; DEWITT, S.F. Normal hematology of the horse and donkey. In: WEISS, D.K.; WARDROP, K.J. Schalm's veterinary hematology. 6.ed. Iowa: Wiley-Blackwell, 2010. Chap.106, p.821-828. 1232 pages.

HODGSON, J.L.; HODGSON, D.R. Inflammatory airway disease. In: LEKEUX, P. (Ed.). Equine respiratory disease. Ithaca: International Veterinary Information Service, 2002. Available from: <http://www.ivis.org/special_books/Lekeux/ hodgson/chapter_frm.asp?LA=1>. Accessed: set. 11, 2003.

HOFFMAN, A.M.; VIEL, L. Techniques for sampling the respiratory tract of horses. Veterinary Clinics of North America - Equine Practice, v.13, n.3, p.463-475, 1997.

HOFFMAN, A.M. Bronchoalveolar lavage technique and cytological diagnosis of small airway inflammatory disease. Equine Veterinary Education, v.11, n.6, p.330-336, 1999.

HOFFMAN, A.M. Bronchoalveolar lavage: sampling technique and guidelines for cytologic preparation and interpretation. Veterinary Clinics of North America: Equine Practice, v.24, n.2, p.423-435, 2008.
HOUSTON, D.M.; RADOSTITS, O.M. O exame clínico. In: RADOSTITS, O.M. et al. Exame clínico e diagnóstico em veterinária. Rio de Janeiro: Guanabara Koogan, 2002. Cap.6, p.81.

LAPOINTE, J.M. et al. Effects of centrifugation and specimen preparation technique on bronchoalveolar lavage analysis in horses. Equine Veterinary Journal, v.26, n.3, p.227-229, 1994.

LESSA, D.A.B. Doença Inflamatória de Vias Aéreas (DIVA) em equinos de policiamento na cidade do Rio de Janeiro, RJ: estudo clínico e da atividade macrofágica alveolar. 2003. 102f. Thesis (PhD in Veterinary Medicine) - Faculdade de Medicina Veterinária e Zootecnia, Universidade de São Paulo, SP.

LESSA, D.A.B. et al. Lavado broncoalveolar em equinos: revisão de literatura. Parte 1: técnicas de coleta. Arquivos de Ciências Veterinárias e Zoologia da Unipar, v.8, n.2, p.213-217, 2005. Available from: <http://www.revistasunipar.br/veterinaria/ article/viewFile/60/41>. Accessed: jan. 14, 2006.

LESSA, D.A.B. et al. Doença Inflamatória das vias aéreas (DIVA) em equinos de policiamento na cidade do Rio de Janeiro, RJ: estudo clínico. Revista Brasileira de Ciência Veterinária, v.15, p.88-93, 2008.

MAIR, T.S. et al. Cellular content of secretions obtained by lavage from different levels of equine respiratory tract. Equine Veterinary Journal, v.19, n.5, p.458-462, 1987.

McGORUM, B.C. et al. Exame clínico do trato respiratório. In: RADOSTITS, O.M. et al. (Ed.). Exame clínico e diagnóstico em veterinária. Rio de Janeiro: Guanabara Koogan, 2002. Cap.16, p.231-269.

MOORE, B.R. et al. Cytologic evaluation of bronchoalveolar lavage fluid obtained from Standardbred racehorses with inflammatory airway disease. American Journal of Veterinary Research, v.56, n.5, p.562-567, 1995.

ROBINSON, N.E. International workshop on equine chronic airway disease. Equine Veterinary Journal, v.33, n.1, p.5$19,2001$.

ROBINSON, N.E. Inflammatory airway disease: defining the syndrome. Conclusions of the Havemeyer Workshop. Equine Veterinary Education, v.15, n.2, p.61-63, 2003.

SWEENEY, C.R. et al. Effect of lung site and volume on results of bronchoalveolar lavage fluid analysis in horses. American Journal of Veterinary Research, v.53, n.8, p.1376-1379, 1992.

VIEL, L. Small airway disease as a vanguard for chronic obstructive pulmonary disease. Veterinary Clinics of North America - Equine Practice, v.13, n.3, p.549-560, 1997.

VIEL, L.; HEWSON, J. Bronchoalveolar lavage. In: ROBINSON, N.E. (Ed.). Current therapy in equine medicine. 5.ed. Philadelphia: Saunders, 2003. p.407-411.

VRINS, A. et al. A retrospective study of bronchoalveolar lavage cytology in horses with clinical findings of small airway disease. Journal of Veterinary Medicine Series A, v.38, n.6, p.472479, 1991.

WINDER, N.C. et al. Comparison of respiratory secretion cytology and pulmonary histology in horses. Journal of Veterinary Medicine Series A, v.36, p.32-38, 1989. 